\title{
AGAMA DAN KEADILAN GENDER
}

\author{
Umi Sumbulah \\ Dosen Fakultas Syari'ah UIN Malang, Sekretaris PSG UIN Malang \\ dan Kandidat Doktor IAIN Sunan Ampel Surabaya
}

\begin{abstract}
ABSTRAK
All religions aim to bring justice for all human beings, for men and women. The aim is stated in normative doctrines of each religion. Nonetheles, the interpretation of religious doctrines as well as the religious practices tend to negate universal religious values which respect the equality and justice for both sexes. This reduction is mostly practiced in interpreting the particular texts of doctrines. Consequently, the great meaning of religion is deviated and reduced by subjective interests of the interpreters. Overall, the problem of inequality and injustice is commmonly a result of religious normative doctrines misinterpretation.
\end{abstract}

\section{A. Pendahuluan}

Perjuangan melawan ketidakadilan gender adalah keharusan sejarah. Kendati demikian, untuk mewujudkannya selalu mendapatkan tantangan. Historisitas adanya pembedaan gender terjadi melalui proses yang sangat panjang dan beragam. Di antaranya adalah karena dibentuk, disosialisasikan, diperkuat dan bahkan dikonstruksi secara sosial maupun kultural, baik melalui interpretasi teks-teks keagamaan ataupun oleh negara. Di sinilah sebenarnya akar penyebab utama dianggapnya perbedaan gender sebagai kodrat Tuhan yang tidak bisa dirubah dan dipertukarkan antara kedua jenis mahluk tersebut, sehingga melahirkan ketidakadilan gender (gender inequalities), baik bagi kaum laki-laki maupun perempuan. Perbedaan gender tidak menjadi masalah sepanjang tidak melahirkan ketidakadilan, tetapi ia menjadi persoalan karena perbedaan gender ini seringkali menimbulkan ketidakadilan. 
Adapun bentuk-bentuk ketidakadilan gender dimaksud adalah stereotipe, marjinalisasi, subordinasi, diskriminasi, tindak kekerasan dan beban kerja. Oleh karena itu diperlukan upaya menciptakan relasi laki-laki dan perempuan yang adil dan harmonis serta bagaimana membentuk sikap yang asertif dalam merespon masalah-masalah gender. Tradisi agama dalam dimensi historis memiliki sumbangan tersendiri bagi pelanggengan fenomena ketidakadilan gender. Beragam citra yang bernuansa pejoratif, dapat dilihat pada penggambaran-penggambaran paradoksal tentang perempuan. Di satu sisi, perempuan sebagai sosok yang memiliki martabat yang setara dengan laki-laki, tetapi di sisi lain digambarkan memiliki posisi yang rendah.

\section{B. Perempuan dalam Perspektif Agama-agama}

\section{Perempuan dalam Tradisi Hinduisme}

Berdasarkan pada teks-teks Sansekerta yang memperlihatkan pengaruh dan bias Brahman, kemaskulinan dan tradisi India utara, perempuan dalam tradisi Hinduisme memiliki posisi yang tidak setara dengan laki-laki. Hal ini misalnya tergambar dalam kehidupan anak-anak ahli Weda. Ia hanya diajari beberapa himne dan detail ritual untuk mempersiapkan peranannya sebagai isteri. Seorang Ibu juga hanya akan melatih anak perempuannya untuk melakukan aktivitas domestik. Demikian juga dalam hal pendidikan, sehingga akses laki-laki dan perempuan sangat senjang. Dalam kitab-kitab Brahman, perempuan diposisikan sebagai silent partner, kecuali dalam ritual kelahiran anak atau pemberkatan cucu. ${ }^{1}$ Kendati Hinduisme menghargai perempuan sebagai ibu, namun perempuan secara umum terutama di abad pertama SM, seperti diposisikan sebagai kasta sudra, yang identik dengan kebodohandan kerendahan.

\section{Perempuan dalam Tradisi Budhisme}

\footnotetext{
${ }^{1}$ Arvind Sharma (ed.), Perempuan Dalam Agama-agama Dunia, Jakarta: Ditpertais Depag RI-CIDAMcGill Project, 2002: 79.
} 
Dalam tradisi Budhisme, sejak awal memberikan tempat kepada perempuan egaliter dengan laki-laki. Hal ini misalnya dapat dilihat betapa perempuan dan laki-laki memiliki hak yang sama dalam menempuh jalan spiritual untuk mencapai Nirwana. Hal ini termaktub dalam teks: "Siapapun yang memiliki seuah kendaraan seperti itu, baik perempuan maupun laki-laki, sesungguhnya dengan mempergunakan kendaraan tadi, ia akan mencapai Nirwana" (S.1.3). Budhisme juga memiliki ordo rahib perempuan, dia dapat mencapai arhant (Nirwana). Karenanya, rintangan utama untuk mencapai pencerahan bukanlah perempuan, tetapi sikap mental. Namun demikian, dalam aliran Budha Mahayana, perempuan diposisikan lebih rendah daripada laki-laki. ${ }^{2}$

\section{Perempuan dalam Tradisi Yahudi}

Dalam tradisi Yudaisme, perempuan di satu sisi digambarkan sebagai mahluk ang kuat, baik dan sopan, sepeti: Batsheba sebagai perempuan yang pandai, Deborah seorang nabi perempuan, Ruth seorang yang terpandang dan Esther seorang juru selamat rakyatnya. Namun, dalam tradisi Yudaisme, juga ditemukan ajaran bahwa perempuan merupakan asal mula dosa dan juga melalui perempuan manusia akan mati. Laki-laki harus bekerja dan perempuan harus melahirkan dalam kesakitan. ${ }^{3}$ Perempuan yang sedang menstruasi dan 7 hari selebihnya dianggap kotor dan tidak suci, bahkan harus disembunyikan di goagoa gelap atau diasingkan dan sebagainya. Perempuan yang melahirkan, 33 hari dianggap kotor apabila anaknya laki-laki. Kalau anaknya perempuan, maka masa tidak sucinya /kotornya menjadi berlipat. Jika telah selesai masa tidak sucinya, ia harus mencari pendeta untuk membuat penebusan dosa untuknya. Bahkan dalam Talmud, ada teks doa: "saya berterimakasih pada-Mu Tuhan, karena tidak menjadikanku perempuan.” 4

\footnotetext{
${ }^{2}$ Ibid., 130.

3 Ibid., 222.

${ }^{4}$ Ibid., 247.
} 


\section{Perempuan dalam Tradisi Kristen}

Laki-laki dan perempuan, meskpun berbeda dalan berbagai hal, tetap merupakan pribadi-pribadi yang mempunyai nilai yang sama. Karena keduanya diciptakan berdasarkan "gambar" Tuhan. Namun dalam tradisi agama ini, juga terdapat ajaran bahwa kepemimpinan laki-laki bersifat kodrati dan given dari Tuhan. Karenanya, upaya mempersamakan laki-laki dan perempuan dalam konteks ini, juga dianggap sebagai melawan hukum Tuhan. Ajaran semacam ini, tampak pada naskah pasca-Paulus dalam perjanjian Baru, yang mensistematisir agama Kristen Patriarkhal. Dengan demikian, ajaran ini berlawanan dengan sistem ajaran Kristen kerakyatan awal.

Pada gerakan Kristen akhir-akhir ini, terdapat banyak aktivis dan pemikir yang memberikan hak yang sama antara laki-laki dan perempuan. Grimke misalnya, menyatakan bahwa kelemahan wanita dalam hal intelektualitas dan kepemimpinan bukanlah hal yang alami, namun karena adanya penyimpangan-penyimpangan sosial. Sekali perempuan dibebaskan dari ketidakadilan sosial, maka ia akan mendapatkan hak dan kesempatan yang sama. $^{5}$

\section{Perempuan dalam Tradisi Islam}

Islam memandang laki-laki dan perempuan sebagai dua mahluk yang setara. ${ }^{6}$ namun juga terdapat teks-teks yang jika hanya dipahami secara literal, mengesankan bahwa perempuan berada pada posisi yang lebih lemah daripada laki-laki. Untuk itu, memahami teks, harus didasarkan kepada metodologi yang benar, sehingga tidak terjadi pemaknaan dan pemahaman yang kontradiktif. Ini karena kebenaran datang dari Dzat Yang Satu, sehingga tidak mungkin ada paradoksal-paradoksal. Untuk melihat bagaimana

\footnotetext{
${ }^{5}$ Ibid., 277.

${ }^{6}$ QS. Al-Hujurat: 13.
} 
posisi perempuan dalam tradisi Islam, perlu diberikan illustrasi tentang bagaimana citra perempuan pra-Islam.

\section{Perempuan dalam Setting Pra Islam}

Citra perempuan sebelum Islam datang sangat buruk. Hal ini terbukti misalnya dengan ditemukannya mummi perempuan di Mesir menggunakan celana dalam besi yang digembok dan bersepatu besi yang berat dan berukuran kecil untuk membatasi perjalanan perempuan. Mitologi Yunani menggambarkan perempuan sebagai iblis betina (female demon) yang selalu mengumbar nafsu. Tradisi Yahudi-Kristen memojokkan perempuan sebagai penyebab kejatuhahn Adam dari surga, peradaban Sasania-Zoroaster yang menyembunyikan perempuan yang sedang haidh di goa-goa gelap serta peradaban Hindu yang memperabukan (membakar hidup-hidup) para istri di samping suaminya yang meninggal.

Sebagai negara kontinental yang menjadi pusat lalu lintas perdagangan, mengalami persentuhan dengan tradisi yang berkembang di kawasan yang melingkupinya.Bahkan sejarah klasik Mesopotamia yang menjadi titik tolak peradaban umat manusia, tepatnya setelah munculnya tokoh Hammurabi yang membuat sederetan aturan hukum yang terangkum dalam kode Hammurabi, aturan tersebut kemudian terekam dalam kitab-kitab klasik, termasuk di antaranya kitab Talmud yang berpengaruh besar pada kitab-kitab tafsir (seperti al-Thabari, Ibn Katsir dan al-Qurthubi). ${ }^{7}$ Di sinilah letak persentuhan bahkan menjadi bagian dari tradisi intelektual Islam yang sangat kental. Oleh karena itu, logis kalau masyarakat Arab era jahili juga mendudukkan kaum perempuan dalam tempat yang sangat rendah.

\footnotetext{
${ }^{7}$ Nasaruddin Umar, Argumen Kesetaraan Gender. Bandung: Mizan, 2002:109.
} 
Pembedaan peran secara sosiologis yang didasarkan pada anatomi biologis ini pada kehidupan Arab jahili bahkan hingga awal-awal Islam dilahirkan paling tidak dipengaruhi oleh beberapa hal : pertama, kondisi suatu wilayah tertentu menyangkut geografis, topografis, demografis, klimatologis dan lain-lain yang berhubungan dengan ekologi jazirah arab era itu. Debet air yang ditentukan oleh besar kecilnya oase juga turut menentukan besar kecilnya anggota kabilah, dan besar kecilnya anggota kabilah juga turut menetukan status sosial anggota kabilah bersangkutan. ${ }^{8}$ Kedua, perebutan sumber air, lahan ternak bahkan perempuan sering menjadi pemicu terjadinya perang antar kabilah (tribalisme). Dalam kondisi sepereti ini maka kemudian perempuan dianggap dan diperlakukan sebagai harta. Karenanya, peristiwa dan tradisi penguburan anak perempuan (dafn al-banat) dilakukan. Paling tidak menurut Reuben Levy, ${ }^{9}$ hal ini dimotivasi: a)Kekhawatiran akan kemiskinan dan dalam hal ini perempuan menjadi alternatif utama untuk dikorbankan mengingat posisinya dalam kabilah tidak dianggap sebagai mahluk produktif; b)sebagai persembahan kepada dan atas nama Tuhan; c)untuk mempertahankan status sosial dan mencegah terjadinya aib dalam keluarga/kabilah.

Berbeda dengan perempuan pra Islam, Rasulullah adalah seorang revolusioner yang membawa perubahan besar bagi kehidupan perempuan khususnya, dan bagi semua segi kehidupan pada umumnya. Perempuan tidak lagi dipandang sebagai mahluk nomor dua (the second class) tetapi sama derajat dan eksistensinya dengan laki-laki. Hal ini terbukti dengan dekonstruksi yang dilakukan oleh Rasulullah terhadap cara pandang bangsa Arab yang menganggap rendah kaum perempuan, ketika kelahiran putrinya Fatimah. Dekonstruksi dilakukan dengan cara membawa fatimah berkeliling Ka'bah, Kondisi ini berbanding terbalik dengan budaya Arab era itu. Di samping itu, dekonstruksi tersebut juga

\footnotetext{
${ }^{8}$ Nasaruddin Umar, Gender dalam Islam, Makalah TOT Penyadaran Gender dan Hak-hak Reproduksi Dalam Islam, PSW-IAIN Sunan kalijaga Yogyakarta, 1999: 6.

${ }^{9}$ Reuben Levy sebagaimana disebutkan oleh Nasaruddin Umar, Argumen Kesetaraan, 92.
} 
untuk membantah terhadap julukan al-abtar (yang terputus ekornya), hanya karena tidak memiliki keturunan laki-laki yang dianggap bisa menjadi generasi penerus.

Kepedulian dan pembelaan terhadap kaum perempuan terus dilakukan oleh Rasulullah. Ini terbukti dari teladan beliau :'Sebaik-baik kamu adalah yang terbaik terhadap istrinya dan aku adalah yang terbaik terhadap istriku", dan beberapa hadis lain yang senada dengan itu. Di era Nabi, banyak sekali kaum perempuan yang menjadi sahabat yang mentransformasikan ilmu pengetahuan dari beliau. Bahkan Ruth Roded, ${ }^{10}$ menyebutkan 1200 perempuan pernah terlibat dalam halaqah ilmiah nabi. Namun realitas penghargaan yang mengesankan terhadap kaum perempuan tersebut tidak atau kurang diikuti oleh para pengganti beliau.

\section{Isu Ketidaksetaraan Gender dalam Islam: Problem Penafsiran}

Terdapat beberapa isu ketidaksetaraan (an-equality) antara laki-laki dan perempuan, serta mengisyaratkan adanya superioritas laki-laki atas perempuan, antara lain: sebagaimana termuat dalam QS. al-Nisa:1 tentang proses penciptaan perempuan dan QS.al-Nisa: 34 tentang kepemimpinan laki-laki atas perempuan, kewarisan laki-laki dan perempuan, persaksian perempuan serta hak-hak reproduksi perempuan. Secara detail bisa dilihat pada tabel berikut :

\footnotetext{
${ }^{10}$ Azyumardi Azra, Perempuan Dalam Sejarah Islam, 1999.
} 


\begin{tabular}{|c|c|c|c|}
\hline No & Isu & $\begin{array}{l}\text { Mufassir Klasik/Metode } \\
\text { Tahlili- Tekstual }\end{array}$ & $\begin{array}{l}\text { Feminis-Mufassir } \\
\text { Kontemporer/Metode } \\
\text { Mawdhu'i-Kontekstual }\end{array}$ \\
\hline 1. & $\begin{array}{l}\text { Penciptaan } \\
\text { perempuan } \\
(\text { QS.4:1) }\end{array}$ & Hawa tercipta dari adam & Hawa dicipta dari nafs wahidah \\
\hline 2. & $\begin{array}{l}\text { Kepemimpinan } \\
\text { Laki-laki atas } \\
\text { perempuan } \\
(\text { QS.4:34) }\end{array}$ & $\begin{array}{l}\text { Kepemimpinan laki-laki } \\
\text { bersifat normatif-kodrati } \\
\text { dan perempuan sebagai } \\
\text { "konco wingking" }\end{array}$ & $\begin{array}{l}\text { Kepemimpinan laki-laki bersifat } \\
\text { kontekstual-tidak kodrati }\end{array}$ \\
\hline 3. & $\begin{array}{l}\text { Persaksian laki- } \\
\text { laki dan } \\
\text { perempuan } \\
\text { (QS. 2: 282) }\end{array}$ & $\begin{array}{l}\text { Persaksian di semua } \\
\text { aspek, jika perempuan } \\
\text { menjadi saksi, maka } \\
\text { harganya separuh laki-laki }\end{array}$ & $\begin{array}{l}\text { Persaksian hanya dalam } \\
\text { muamalah, harga separuh dari } \\
\text { laki-laki }\end{array}$ \\
\hline 4. & $\begin{array}{l}\text { Kewarisan laki- } \\
\text { laki dan } \\
\text { perempuan } \\
(Q S .4: 11)\end{array}$ & $\begin{array}{l}\text { Normatif-tekstual 2:1. } \\
\text { dalam kondisi apapun dan } \\
\text { bagaimanapun, harta } \\
\text { warisan harus dibagi } \\
\text { dengan komposisi 2:1. } \\
\text { Dengan demikian, } \\
\text { "harga" pertempuan } \\
\text { separuh dari harga laki- } \\
\text { laki. }\end{array}$ & $\begin{array}{l}\text { Pemahaman kontekstual, dengan } \\
\text { mempertimbangkan setting } \\
\text { historis dan kemaslahatan } \\
\text { (misal: karena perempuan tidak } \\
\text { wajib menafkahi dirinya,karena } \\
\text { saudara laki-laki rela dan sudah } \\
\text { mapan). }\end{array}$ \\
\hline 5. & $\begin{array}{l}\text { Hak-hak } \\
\text { reproduksi } \\
\text { (QS.2: 223) }\end{array}$ & $\begin{array}{l}\text { Hak penuh laki-laki } \\
\text { berhubungan seksual, } \\
\text { kapan-di manapun }\end{array}$ & $\begin{array}{l}\text { Ayat ini merupakan koreksi atas } \\
\text { tradisi anal bangsa Arab jahili; } \\
\text { penghargaan perempuan seperti } \\
\text { ladang, dan pesan moral agar } \\
\text { perempuan diperlakukan secara } \\
\text { baik dan proporsional }\end{array}$ \\
\hline
\end{tabular}

\section{Konsep Penciptaan Perempuan}


Tema sentral QS. al-Nisa': 1 adalah ungkapan nafs wahidah dan zaujaha. Para mufassir klasik baik sunni, syi'i maupun i'tizali sekalipun hampir semua sepakat bahwa nafs wahidah diartikan sebagai Adam dan otomatis zaujaha sebagai Hawa. Sehingga karenanya, Hawa diciptakan dari Adam (tulang rusuk). Sementara kalangan mufassir kontempoter (dalam hal ini penafsiran mereka banyak diadopsi dan dielaborasi oleh kaum feminis) dengan analisis semantik dan mengaitkannya dengan ayat-ayat lainnya, mengartikan bahwa Hawa diciptakan dari jenis yang sama dengan Adam. Sehingga Adam dan Hawa, dalam konteks ini laki-laki dan perempuan setara dalam proses dan substansi penciptaannya.

Tanggapan para mufassir kontemporer terhadap interpretasi mufassir klasik yang menganggap laki-laki adalah superior atas perempuan, bahwa mereka terinfiltrasi oleh beberapa hal : pertama, metode penafsiran yang terpaku pada tahlili (kronologis, tekstual, terpaku pada keumuman lafadz dan terikat oleh tradisi Timur Tengah yang androsentris) dan mengabaikan metode maudhu'i (tematis, kontekstual, dan memperhatikan logika kekhususas sebab). Kedua, Infiltrasi Israiliyat yang terserap pada pada teks hadis Nabi, yang berasal dari sumber-sumber tradisi Yahudi dan Nasrani.

\section{Posisi dan Kepemimpinan Laki-laki atas Perempuan}

Penafsiran terhadap QS. 4:34, butir ayat yang berbicara tetang posisi dan kepemimpinan laki-laki atas perempuan, marupakan satu masalah yang sering dijadikan contoh oleh kalangan feminis muslim untuk menunjukkan bagaimana diskriminatifnya penafsiran tradisional terhadap perempuan. Bias gender berupa penempatan laki-laki di atas perempuan, selanjutnya menandai bagaimana penafsir selalu berusaha menempatkan laki-laki pada posisi superior. Karenanya, para feminis muslim menyepakati tentag 
perlunya memahami ayat ini melalui pendekatan kontekstual, dengan tidak hanya terpaku pada makna literalnya serta mengkaji konteks asbabul wurud-nya.

Jika pada umumnya mufassir klasik (dari mazhab apapun) --lewat pemahaman mereka terhadap ungkapan qawwam-- menggunakan ayat ini sebgai sebuah legalitas normatif kepemimpinan laki-laki atas perempuan --dalam rumah tangga saja atau sekaligus dalam milleau dan aspek yang lebih luas, maka menurut Asghar Ali Engineer, dengan hanya bersandar pada aspek literal ayat ini tidak cukup untuk menunjukkan bahwa alQur'an memutlakkan kepemimpinan laki-laki terhadap perempuan. ${ }^{11}$ Apabila memperhatikan konsideran ayat tersebut (wa bima anfaqu min amwalihim) dan mengaitkannya dengan QS.2:228, maka sebenranya ayat tersebut hanya berbicara tentang kepemimpinan rumah tangga (suami terhadap istri) dan inipun hanya dalam hal fungsi ekonomisnya.

\section{Hak-hak Reproduksi Perempuan}

Dalam Islam, dikenal dua ajaran, yakni ajaran dasar dan non-dasar. Hak-hak reproduksi perempuan lebih banyak terklasifikasi pada kategori terakhir, karena ia merupakan interpretasi secara kultural terhadap ajaran dasar. Karenanya, ia berrsifat lokal dan relatif (dzanny), berbeda debgan ajaran dasar yang bersifat universal, tidak terikat ruang dan waktu serta mutlak (qath'iy).

Lies Marcoes Natsir, ${ }^{12}$ menyatakan bahwa wacana seputar hak-hak reproduski perempuan tidak bisa dibicarakan secara terpisah dari wacana keagamaan. Jika sudah masuk wilayah keagamaan, berarti kita harus bekerja keras menumbangkan fiqh yang patriakhat, untuk menuju fiqh emansipatoris yang berkeadilan (tidak hanya pada relasi kaya-miskin) tetapi juga relasi gender (laki-laki dan perempuan). Hak-hak reproduksi

\footnotetext{
${ }^{11}$ Asghar Ali Engeenir, Hak-hak Perempuan Dalam Islam, Yogyakarta: Bentang Budaya, 1997.

${ }^{12}$ Lies Marcoes Natsir, "Hak-hak Reproduksi Perempuan dalam Islam," dalam Jurnal Perempuan Dan Gender Dalam Islam, 1999, 2.
} 
perempuan yang meliputi : hak untuk memilih pasangan hidup, menentukan jumlah anak, memilih kontrasepsi, mendapatkan informasi kesehatan, menghentikan kehamilan yang tidak dikehendaki serta menikmati hubungan seksual dengan suaminya, seringkali berhadapan dengan "tembok tebal" yang terdiri dari barisan aturan yang didominasi oleh pandangan budaya dan agama. Isu-isu tentang persaksian dan kewarisan, juga dipahami secara tekstual oleh para mufassir dan dikonsumsi serta dipraktikkan oleh mayoritas umat Islam

\section{E. Membangun Pola Relasi Berkeadilan Gender dalam Islam}

Di dalam al-Qur'an tidak ada padanan kata gender. Namun jika yang dimaksud gender adalah menyangkut perbedaan laki-laki dan perempuan secara non-biologis yang meliputi peran, fungsi dan relasi antara kedua jenis mahluk tersebut, maka terdapat sejumlah istilah untuk itu. Istilah dimaksud al: al-rajul/al-rijal dan al-mar'ah/al-nisa', aldzakar dan al-untsa, termasuk gelar status untuk laki-laki dan perempuan seperti al-zauj, al-zaujah, al-ab-al-umm, al-akh-al-ukht, al-jadd-al-jaddah, al-muslimun-al-muslimat dan sebagainya. ${ }^{13}$

Adalah menarik dikaji berkaitan dengan konsistensi al-Qur'an dalam menggunakan terma-terma tersebut untuk mengungkapkan fenomena-fenomena tertentu. Misalnya jika ingin mengungkapkan laki-laki dan perempuan dari aspek biologis, maka al-Qur'an menggunakan kata al-dzakar (male) untuk laki-laki dan al-untsa (female) untuk perempuan. Dalam banyak ayat, terma ini juga digunakan untuk mengungkapkan jenis kelamin binatang, ${ }^{14}$ malaikat, ${ }^{15}$ dan syaitan. ${ }^{16}$ Ini berarti bahwa antara keempat jenis mahluk tersebut secara biologis tidak berbeda. Sementara itu, jika yang ingin diungkapkan

\footnotetext{
${ }^{13}$ Nasaruddin Umar. Argumen, 65.

${ }^{14}$ QS. al-An'am: 148.

15 QS. al-Isra: 40.

${ }^{16}$ QS. al-Nisa:17.
} 
berkaitan dengan beban sosial (gender assignment) atau aspek gender, maka al-Qur'an seringkali menggunakan istilah al-rajul /al-rijal antuk laki-laki dan al-nisa' untuk perempuan. Terma-terma tersebut tidak pernah digunakan oleh al-Qur'an untuk mahluk biologis selain manusia.

Nasarudin Umar, ${ }^{17}$ meneliti lebih jauh berkaitan dengan istilah-istilah umum yang menunjuk mahluk laki-laki dan perempuan. Kata al-ins digunakan untuk membedakan manusia dari komunitas jin, ${ }^{18}$ al-insan untuk menggambarkan keutamaan manusia yang bermartabat sebagai khalifah, ${ }^{19}$ al-basyar untuk menggambarkan manusia sebagai mahluk biologis yang bu6tuh makan,minum dan berhubungan seks (QS.3:47), dan kata bani Adam umumnya digunakan untuk menunjuk kemuliaan harkat dan martabat manusia secara keseluruhan tanpa membedakan jenis kelamin, ras dan etnis (QS.17:70). Dengan demikian segregasi peran dengan hanya melihat jenis kelamin tanpa melihat konteks bagaimana ayat tersebut diberlakukan, merupakan sebuah kekeliruan.

Diakui memang al-Qur'an mengungkapkan perbedaan mendasar antara laki-laki dan perempuan, tetapi harus dicermati kembali apakah ungkapan tersebut mengacu kepada unsur biologis, unsur budaya atau keduanya sekaligus. Seringkali ayat-ayat al-Qur'an yang menunjukkan kekhususan-kekhususan perempuan seperti menstruasi, menopause, hamil dan sebagainya, disalahpahami bahkan dijadikan sebagai alat untuk memojokkan perempuan pada sektor domestik. Ironisnya, ayat-ayat tersebut sering diasosiasikan dengan ayat lain yang menyatakan bahwa laki-laki mempunyai satu tingkat kelebihan di atas kaum perempuan, ${ }^{20}$ dan ayat yang menyatakan bahwa kaum laki-laki itu pemimpin bagi kaum perempuan. ${ }^{21}$ Padahal al-Qur'an tidak pernah mengungkapkan bahwa fungsi

\footnotetext{
${ }^{17}$ Nasaruddin Umar, Gender dan Islam, 11.

${ }^{18}$ QS. Al-A'raf: 179.

${ }^{19}$ QS. Al-'Alaq:4-5.

${ }^{20}$ QS. al-Baqarah: 228.

${ }^{21}$ QS.al-Nisa: 34.
} 
reproduksi kaum perempuan menjadi sebab atau alasan yang menjadikan kaum perempuan sebagai mahluk subordinate (the second sex).

Fenomena interpretasi teks-teks suci berkaitan dengan konsep gender yang mendiskreditkan kaum perempuan ini, menurut kesimpulan beberapa feminis muslim, disebabkan oleh beberapa hal: 1)belum jelasnya konsep seks dan gender dalam mendefinisikan peran laki-laki dan perempuan; 2)ilfiltrasi israiliyat dalam teks-teks suci yang berkembang di kawasan Timur Tengah; 3)metode interpretasi yang mengandalkan metode tahlili dan bukan maudhui; 4)kemungkinan ketidaknetralan para mufassir dalam mencermati teks. Karena itu, perlu adanya penggalakan interpretasi teks dengan metode maudhu'i, yang sangat menekankan aspek kontekstual/sosial-budaya ketika ayat tersebut turun, sehingga melahirkan pemahaman yang berkesetaraan dan berkeadilan gender.

Di samping penafsiran teks yang kurang "berkeadilan" pembedaan peran laki-laki dan perempuan ini juga sangat dipengaruhi oleh kondisi sosio-kultural serta ekologi suatu kawasan tertentu. Di Indonesia misalnya, memiliki konsepsi relasi gender yang berbeda dengan konsepsi relasi gender yang berkembang di kawasan Timur Tengah, kendati kedua kawasan ini sama-sama memiliki penduduk yang mayoritas muslim. Perbedaan konsepsi relasi gender tersebut, disebabkan oleh kondisi obyektif geografis dan latar historis yang berbeda, sehingga tafsiran-tafsiran teks dalam dataran normatif intelektual serta dalam dataran praktis implementasinya juga sangat memungkinkan berbeda.

Secara normatif, terdapat teks-teks keagamaan (al-Qur'an-Hadits), yang jika dipahami secara literal akan memberi kesan adanya ketidaksejajaran (superioritasinferiotitas) antara laki-laki dan perempuan. Teks-teks dimaksud di antaranya adalah yang berbicara tentang proses penciptan perempuan, kepemimpinan laki-laki atas perempuan, hak-hak reproduksi perempuan, hak kewarisan dan persaksian perempuan dan sebagainya. 
Teks-teks keagamaan tersebut, seharusnya tidak didekati secara normatif an sich, namun juga harus didekati secara kontekstual. Karena jika tidak, akan mereduksi dan bertentangan dengan semangat teks-teks keagamaan lainnya, yang secara substansial mengakui adanya prinsip kesetaraan antara laki-laki dan perempuan. Di antaranya perempuan dan laki-laki sejajar di hadapan Allah, kecuali karena kadar ketaqwaannya. ${ }^{22}$ Laki-laki dan perempuan yang beriman berkesempatan yang sama untuk mendapat ganjaran dari Tuhan. ${ }^{23}$

Al-Qur'an memberikan beberapa isyarat jelas tentang prinsip dasar kemanusiaan, yakni: kesetaraan, keadilan, persamaan, tasamuh, keseimbangan, demokrasi musyawarah serta penegakan HAM (al-dahruriyahal-khamsah). Penghargaan terhadap perempuan tersebut, dapat dilihat pada berbagai aspek: hak-hak dalam rumah tangga : laki-laki dan perempuan sebagai libas $;^{24}$ hak-hak reproduksi perempuan (nikah, mahar, memilih pasangan, memperoleh nafkah, jaminan kesehatan reproduksi, mu'asyarah bil ma'ruf, menentukan kehamilan, merawat anak, perceraian dan sebagainya; hak-hak beraktivitas pada domain publik; ${ }^{25}$ hak-hak dalam hukum (kesaksian perempuan) ${ }^{26}$; hak-hak politik (peran politik Ratu Saba') ${ }^{27}$

Apabila relasi gender mengakibatkan ketimpangan atau ketidakadilan, berarti ada masalah dan semestinya ada indikator univerasal yang diakui PBB untuk mengatakan apakah sudah ada keadilan dan tidak terjadi kekerasan. Indikator itu disebut human being basic need, yaitu: pangan, kesehatan, pendidikan, akses ekonomi, politik dan sosial budaya.Oleh karena itu perlu direnungkan apakah laki-laki dan perempuan di lingkungan kita sudah mendapat akses setara terhadap human basic needs di atas.

\footnotetext{
${ }^{22}$ QS.al-Hujurat:13.

${ }^{23}$ QS. Ali Imran:195.

${ }^{24}$ QS. al-Baqarah: 187.

${ }^{25}$ QS. al-Ahzab: 33.

${ }^{26}$ QS. Al-Baqarah: 282

${ }^{27}$ QS. Al-Naml: 32-35.
} 
Untuk mewujudkan relasi gender yang berkeadilan, sedapat mungkin dihilangkan kesenjangan hubungan dan pembagian kerja secara seksual antara laki-laki dan perempuan dalam berbagai ruang kehidupan, tentunya dengan memperhatikan kodratnya. Ketidakadilan gender merupakan hal yang harus dikikis habis, agar perempuan dan lakilaki dapat berdiri pada posisi setara, sehingga tidak ada keunggulan apriori yang satu terhadap yang lain.

Dalam Islam, dijelaskan bahwa laki-laki dan perempuan memiliki kesetaraan potensi untuk mencapai stratifikasi tertinggi di hadapan Tuhan $;^{28}$ Tuhan juga memberikan penghargaan yang sama antara karya positif laki-laki dan karya positif yang dihasilkan perempuan, dengan harga yang sama. ${ }^{29}$ Karena itu, tidak sepatutnya ajara-ajaran dasariah dan qath'iy seperti ini terediuksi keagungannya dengan masalah-masalah yang nondasariah dan $d z a n n y$, seperti masalah kewarisan ${ }^{30}$ penciptaan perempuan, ${ }^{31}$ kepemimpinan laki-laki atas perempuan ${ }^{32}$ dan lainnya, yang kesemuanya terkait erat dengan konteks dan setting sosio-kultural yang melatarbelakangi turunnya ayat-ayat tersebut.

Al-Qur'an mengungkapkan perbedaan mendasar antara laki-laki dan perempuan, tetapi harus dicermati kembali apakah ungkapan tersebut mengacu kepada unsur biologis, unsur budaya atau keduanya sekaligus atau kepada acuan lain. Seringkali ayat-ayat alQur'an yang menunjukkan kekhususan-kekhususan perempuan seperti menstruasi, menopause, hamil dan sebagainya, disalahpahami bahkan dijadikan sebagai alat untuk memojokkan perempuan pada sektor domestik. Ironisnya, ayta-ayat tersebut sering diasosiasikan dengan ayat lain yang menyatakan bahwa laki-laki mempunyai satu tingkat kelebihan di atas kaum perempuan, ${ }^{33}$ dan ayat yang menyatakan bahwa kaum laki-laki itu

\footnotetext{
${ }^{28}$ QS. Al-Hujurat:13.

${ }^{29}$ QS. Ghafir:40.

${ }^{30}$ QS. al-Nisa: 11 .

${ }^{31}$ QS.al-Nisa:1.

${ }^{32}$ QS.al-Nisa: 34.

${ }^{33}$ QS.al-Baqarah: 228.
} 
pemimpin bagi kaum perempuan. ${ }^{34}$ Padahal al-Qur'an tidak pernah mengungkapkan bahwa fungsi reproduksi kaum perempuan menjadi sebab atau alasan yang menjadikan kaum perempuan sebagai mahluk subordinate (the second sex).

Fenomena interpretasi teks-teks suci berkaitan dengan konsep gender yang mendiskreditkan kaum perempuan ini, menurut kesimpulan beberapa feminis muslim, disebbkan oleh beberapa hal : 1) belum jelasnya konsep seks dan gender dalam mendefinisikan peran laki-laki dan perempuan, 2)ilfiltrasi israiliyat dalam teks-teks suci yang berkembang di kawasan Timur Tengah, 3)metode interpretasi yang mengandalkan metode tahlili dan bukan maudhu'i serta 4)kemungkinan ketidaknetralannya mencermati teks. Karena itu, perlu adanya penggalakan interpretasi teks dengan metode maudhu'i, yang sangat menekankan aspek kontekstual/sosial-budaya ketika ayat tersebut turun. Teks yang sesungguhnya tidak netral, kemudian dipahami oleh para pembaca (mufassir, fuqaha', dosen, da'i dan lain-lain) dengan hanya berdasarkan teks, tanpa melihat lebih jauh kapan, di mana dan untuk apa teks itu muncul. Kendati ada perbenturan terus menerus antara pengarang dan pembaca, namun dengan pendekatan yang demokratis tanpa ada hegemoni tertentu, maka isu kesetaraan dan keadilan gender dapat terakomodir di sana.

Perbedaan konsepsi relasi gender tersebut, disebabkan oleh kondisi obyektif geografis dan latar historis yang berbeda, sehingga tafsiran-tafsiran teks dalam dataran normatif intelektual serta dalam dataran paraktis implementasinya juga sangat memungkinkan berbeda.

\section{E. Purna Wacana}

Dalam Islam terdapat ajaran dasar dan jabaran. Oleh karenanya, memahami fenomena teks tersebut harus terlebih dahulu memilahnya dan mendudukkannya pada posisi yang proporsional. Konsep qath'i yang tidak terbatas ruang dan waktu, harus lebih

\footnotetext{
${ }^{34}$ QS. Al-Nisa:34.
} 
diutarakan untuk direalisasikan ketimbang jabaran dzanny yang terbatasi ruang dan waktu. Karena klasifikasi ajaran yang disebutkan terakhir itu mesti terlebih dahulu dipertanyakan kelayakannya untuk diterapkan dalam situasi yang berbeda.

Islam sebagai kekuatan dan penuntun moralitas manusia, sebenarnya sudah digagas oleh banyak pemikir muslim baik di era pra maupun era modern serta para pemikir kontemporer. Sebut saja misalnya Abduh dan Ridha yang menunjukkan Islam sebagai agama yang ramah (tanpa dominasi etnis, ras, agama dan jenis kelamin), Ahmad Khan yang membuktikan bahwa hukum Islam tidaklah kejam serta Amir Ali yang berupaya menunjukkan kekuatan dan semangat egalitarianisme Islam.

Islam adalah agama yang mampu mengadakan perombakan akidah, ibadah, hukum dan lain-lain, yang hal itu merupakan prestasi revolutif Muhammad dengan Islamnya, yang tidak pernah bisa dilakukan oleh agama-agama selainnya/sebelumnya. Pemikirannya tentang perbudakan, poligami dan kedudukan perempuan patut mendapat penghargaan dan acungan jempol.

Teks al-Qur'an menyatakan bahwa di dalamnya tidak ada pertentangan karena ia berasal dari sumber kebenaran Yang satu, yakni Allah. ${ }^{35}$ Berdasarkan ayat tersebut dapat dipahami bahwa al-Qur'an adalah sesuatu dan penafsiran --yang berbeda-beda itu-- adalah sesuatu yang lain. Oleh karena itu, memilih penafsiran tertentu untuk ayat tertentu, tidak boleh dijadikan sebagia justifikasi untuk menyalahkan panafsiran yang lain.

Keragaman interpretasi teks juga disebabkan oleh stratifikasi pemahaman, penghayatan dan pengamalan seseorang dalam keberagamaannya. Sehingga dari modelmodel stratifikasi tersebut jugta akan mengakibatkan adanya penafsiran yang menekankan pada bentuk formal (al-nash) vis a vis penafsiran yang menekankan pada substansiu teks (maqshud al-nash).

\footnotetext{
${ }^{35}$ QS.al-Nisa:82.
} 
Pemahaman terhadap teks terkait dengan persoalan gender, harus didudukkan pada posisi dan porsi yang semestinya, sehingga cita ideal Islam untuk mewujudkan prinsip egalitarianisme bagi laki-laki dan perempuan, tidak hanya menjadi kamuflase akademik semata, namun benar-benar menjadi bentuk pemahaman dan praktik keagamaan yang jauh dari hegemoni, superioritas dan bahkan eksploitasi, amin.

Wallah a'lam bi al-shawab 


\section{BIBLIOGRAFI}

Azra, Azyumardi. Perempuan Dalam Transformasi Sejarah Islam, 1999.

Depag RI, Al-Qur'an dan Terjemahnya.

Engeenir, Asghar Ali. Hak-hak Perempuan Dalam Islam, Yogyakarta: Bentang Budaya, 1997.

Natsir, Lies Marcoes "Hak-hak Reproduksi Perempuan dalam Islam," dalam Jurnal Perempuan Dan Gender Dalam Islam, 1999.

Sharma, Arvind (ed.), Perempuan Dalam Agama-agama Dunia, Jakarta: Ditpertais Depag RI-CIDA-McGill Project, 2002.

Umar, Nasaruddin, Argumen Kesetaraan Gender. Bandung: Mizan, 1999.

---------Gender dalam Islam, Makalah TOT Penyadaran Gender dan Hak-hak Reproduksi Dalam Islam, PSW-IAIN Sunan kalijaga Yogyakarta, 1998. 